\title{
Effect of irrigation and nitrogen application on water productivity and performance of Cotton (Gossypium sp.)
}

\author{
RAKESH KUMAR ${ }^{1 *}$, N.K. PAREEK ${ }^{2}$, V.S. RATHORE ${ }^{3}$ and VINAY NANGIYA ${ }^{4}$
}

Received: 11 June 2019; Accepted: 15 August 2019

\begin{abstract}
An experiment was conducted at research farm, Agricultural research sub-station, Hanumangarh, a unit of Swami Keshwanand Rajasthan Agricultural University, Bikaner during Kharif season, 2016 to study the effect of water and nitrogen application rates on yield attributes, yield and water productivity of cotton (Gossypium sp.). Cotton variety Sri ram 6588 BG II was planted using 3 levels of irrigation (200, 400 and $600 \mathrm{~mm}$ ) and 4 level of nitrogen $\left(0,75,150\right.$ and $\left.225 \mathrm{~kg} \mathrm{ha}^{-1}\right)$ in split plot design with three replications. The water and nitrogen application rates had significant influence on yield attribute, yield and water productivity of cotton. The results indicated that the irrigation level $400 \mathrm{~mm}$ recorded significantly higher number of bolls per plant (37.08), boll weight (3.83 g), seed cotton yield (2568 kg $\left.\mathrm{ha}^{-1}\right)$, lint yield $\left(734 \mathrm{~kg} \mathrm{ha}^{-1}\right)$ and seed yield $\left(1834 \mathrm{~kg} \mathrm{ha}^{-1}\right)$ but was at par with irrigation level $600 \mathrm{~mm}$. The highest stalk yield (4947 $\left.\mathrm{kg} \mathrm{ha}^{-1}\right)$, biological yield (7599 $\left.\mathrm{kg} \mathrm{ha}^{-1}\right)$ and seed index (9.21) were observed with irrigation level $600 \mathrm{~mm}$. However, highest water productivity $\left(0.405 \mathrm{~kg} \mathrm{~m}^{-3}\right)$ was observed with irrigation level $200 \mathrm{~mm}$. The maximum number of bolls per plant (41.78), stalk yield (4745 $\left.\mathrm{kg} \mathrm{ha}^{-1}\right)$, biological yield $\left(7462 \mathrm{~kg} \mathrm{ha}^{-1}\right)$ and water productivity $\left(0.392 \mathrm{~kg} \mathrm{~m}^{-3}\right)$ were found with nitrogen application rate $150 \mathrm{~kg}$ $\mathrm{ha}^{-1}$. The highest boll weight (4.05), seed index (8.47), seed cotton yield (2813 kg ha-1), seed yield (803 kg $\left.\mathrm{ha}^{-1}\right)$ and lint yield (2010 kg ha-1) were observed with nitrogen level $225 \mathrm{~kg} \mathrm{ha}^{-1}$. The irrigation and nitrogen level had no significant effect on plant population at harvest. Irrigation along with nitrogen levels significantly influenced the yield attributes, yields and water productivity of Bt cotton. The combined application of irrigation level $600 \mathrm{~mm}$ and $\mathrm{N} @ 225 \mathrm{~kg} \mathrm{ha}^{-1}$ resulted in significantly higher number of bolls per plant, seed cotton yield, stalk yield and total water productivity in comparison to irrigation@ 200 mm and N@ 0 kg ha ${ }^{-1}$ (control).
\end{abstract}

Key words: Irrigation, Nitrogen, Yield, Water productivity, Cotton

\section{INTRODUCTION}

Any kind of crop production activity mainly confined around the proper management of water and nutrients. It became more important in the hunger and thirsty area like North West Rajasthan, where annual rainfall ranges from $150-350 \mathrm{~mm}$ and available soil nitrogen ranges from $90-130 \mathrm{~kg} \mathrm{ha}^{-1}$ and hence, efficient management of these two factors of crop production can decide crop productivity. The irrigated North Western plain zone $(\mathrm{Ib})$ of Rajasthan, comprising Sriganganagar and Hanumangarh districts, is part of arid tract of India. In this region, low rainfall or unequal distribution of rains during crop growing period affect the crop yield. Hence, irrigation is the utmost important factor for crop production in arid regions throughout the dry season (Dagdelen et al., 2006). In many regions, the water resources and availability of fresh water are decreasing with depletion of water reservoirs and their use in other sectors like urbanization and industrialization. According to Payero et al. (2006), this problem may be faced by farmers from many regions of the world. In this situation the optimization of crop yield and water productivity can be achieved through reducing the amount of irrigation water either by applying less water than required throughout the whole growing season or by avoiding irrigation at less sensitive water stress phases, allowing great economic return (Zegbe Domingues et al., 2003). Nearly $62 \%$ of Indian soils particularly low in organic matter as in arid region, are deficient in nitrogen and adequate supply of nitrogen associated with vigorous vegetative growth leads to more efficient utilization of available inputs and finally to higher crop productivity. Cotton (Gossypium sp.) is a most important fibre and cash crop grown commercially for agricultural and industrial purposes (Smith, 1999). Although cotton is mainly grown for fibre

${ }^{1}$ PG Scholar, ${ }^{2}$ Assistant Professor, Department of Agronomy College of Agriculture, SKRAU, Bikaner-334006, Rajasthan ${ }^{3}$ Principal Scientist, CAZRI, Regional Research Station, Bikaner-334004, , Rajasthan, ${ }^{4}$ Senior Hydrologist, ICARDA, Aleppo, Syria

*Corresponding author Email id: rakeshsarswat58@gmail.com 
purpose but it has many valuable uses as its seed contain $30 \%$ starch, $16.2 \%$ protein and $25 \%$ oil (Cobley and Steel, 1976).

Cotton production is mainly affected by water stress condition (Pettigrew, 2004; Dagdelen et al., 2006; Basal et al., 2009; Rao et al., 2016). Insufficient supply of nitrogen and irrigation causes water and nitrogen stress during the sensitive growth stages, flowering and fruit-setting stages, which can lead to a reduced number of fruiting positions, boll shedding, and poorly developed bolls (Aujla et al., 2005). Contrarily, over-irrigation in cotton can cause undesired more vegetative growth, which may cause reduction in cotton yields (Karam et al., 2006). A properly managed irrigation improves the water productivity and nutrient uptake. Although the high costs to initial investments are a disadvantage, the profits can be quickly recovered with appropriated crop fertilization. So, fertilization should be done only with the quantities required by crop, avoiding deficits or waste. To reach this goal, high yields must be achieved in order to obtain the maximum economic yield of the crop (Zonta et al., 2016). Keeping this in view, the present experiment entitled,"Effect of water and nitrogen application rates on yield attributes, yield and water productivity of cotton (Gossypium sp.)" was carried out during kharif season 2016.

\section{MATERIALS AND METHODS}

The field experiment was conducted during kharif season of 2016 at Agricultural Research Sub Station, Hanumangarh, SKRAU, Bikaner. The soil was silty clay with pH 7.6, having $0.19 \%$ organic carbon, $196.57 \mathrm{~kg} \mathrm{ha}^{-1}$ available $\mathrm{N}, 33.65 \mathrm{~kg} \mathrm{ha}^{-1}$ available $\mathrm{P}$ and $378.12 \mathrm{~kg} \mathrm{ha}^{-1}$ available $\mathrm{K}$. The experiment was laid out in split plot design with three replications. The treatments comprised of 3 irrigation levels $(200,400$ and $600 \mathrm{~mm}$ ) and 4 nitrogen levels $\left(0,75,150\right.$ and $\left.225 \mathrm{~kg} \mathrm{ha}^{-1}\right)$. The cotton variety 'Sri Ram 6588 BG II' was sown manually in $90 \mathrm{~cm} \times 67.5 \mathrm{~cm}$ row and plant spacing on 16 June 2016 . The net plot size was $3.6 \times 4.05 \mathrm{~m}$. A uniform pre sowing irrigation of $60 \mathrm{~mm}$ was applied to all plots. The measured quantity of irrigation to each plot was applied via a 2 inch PVC pipe fitted with water flow meter (Kranti). The plots receiving 200, 400 and $600 \mathrm{~mm}$ irrigation were irrigated at 4 (30, 60, 90 and 120 DAS), $6(30,45,60$, 75, 90 and 120 DAS) and $8(30,45,60,75,90,105$, 120 and 135 DAS) times, respectively. The rate of application of water was $50 \mathrm{~mm}$ each irrigation in case of $I_{200}$ treatment. In, $I_{400}$ treatments the first irrigation was of $50 \mathrm{~mm}$, and rest of 5 irrigations of $70 \mathrm{~mm}$. In case of $\mathrm{I}_{600}$ treatment, the first and second irrigation was of 50 and $70 \mathrm{~mm}$, and rest of 6 irrigations of $80 \mathrm{~mm}$. The nitrogen was applied in the form of urea as per sub plot treatment in three splits viz. 1/3 as basal at sowing, $1 / 3$ at 30 DAS along with $1^{\text {st }}$ irrigation and remaining $1 / 3$ at the time of bud formation at the time of $5^{\text {th }}$ irrigation (90 DAS). The phosphorus was applied @ 40 kg $\mathrm{P}_{2} \mathrm{O}_{5}$ ha $^{-1}$ through SSP as per recommendation of cotton. Five random plants were selected from each plot, excluding the border row, for taking observations on yield attributes. The water productivity was computed by summing up water from irrigation and rainfall during the entire crop season. As there is no meteorological observatory established in Hanumangarh district, hence weekly weather data obtained from nearby district (recorded at meteorological observatory of IMD located at Sriganganagar). Kharif season 2016 experienced a total of $253.8 \mathrm{~mm}$ rainfall during the crop growing season.

\section{RESULTS AND DISCUSSION}

Yield attributes and yields

\section{Irrigation levels}

Irrigation levels significantly influenced the yield and yield attributes viz. number of bolls per plant, boll weight, seed index,harvest index as well as (seed cotton, lint, seed, stalk and biological) yield (Table 1 and 2). Except harvest index, all these parameters increased with increasing levels of irrigation from 200 to $600 \mathrm{~mm}$. Irrigation level 400

Table 1. Effect of irrigation and nitrogen levels on yield attributes of cotton

\begin{tabular}{lcccc}
\hline Treatments & $\begin{array}{c}\text { Plant stand } \\
\text { at harvest } \\
\left({ }^{\prime} 000 \mathrm{ha}^{-1}\right)\end{array}$ & $\begin{array}{c}\text { No. of } \\
\text { bolls per } \\
\text { plant }\end{array}$ & $\begin{array}{c}\text { Boll } \\
\text { weight } \\
(\mathrm{g})\end{array}$ & $\begin{array}{c}\text { Seed } \\
\text { index } \\
(\mathrm{g})\end{array}$ \\
\hline Irrigation levels & & & & \\
$\mathrm{I}_{200}$ & 16.00 & 31.58 & 3.14 & 6.50 \\
$\mathrm{I}_{400}$ & 16.07 & 37.08 & 3.45 & 8.42 \\
$\mathrm{I}_{600}$ & 16.15 & 40.58 & 3.83 & 9.21 \\
$\mathrm{SEm} \pm$ & 19.44 & 1.39 & 0.10 & 0.18 \\
$\mathrm{CD}(P=0.05)$ & $\mathrm{NS}$ & 5.45 & 0.39 & 0.72 \\
$\mathrm{Nitrogen} \mathrm{levels}$ & & & & \\
$\mathrm{N}_{0}$ & 16.10 & 24.67 & 2.81 & 7.49 \\
$\mathrm{~N}_{75}$ & 16.18 & 34.22 & 3.30 & 8.05 \\
$\mathrm{~N}_{150}$ & 16.21 & 41.78 & 3.73 & 8.17 \\
$\mathrm{~N}_{225}$ & 16.25 & 45.00 & 4.05 & 8.47 \\
$\mathrm{SEm} \pm$ & 41.43 & 1.56 & 0.07 & 0.09 \\
$\mathrm{CD}(P=0.05)$ & $\mathrm{NS}$ & 4.63 & 0.22 & 0.29 \\
\hline
\end{tabular}


Table 2. Effect of irrigation and nitrogen levels on yields $\left(\mathrm{kg} \mathrm{ha}^{-1}\right)$ and harvest index (\%) of cotton

\begin{tabular}{lccccccc}
\hline Treatments & $\begin{array}{c}\text { Seed cotton } \\
\text { yield } \\
\left(\mathrm{kg} \mathrm{ha}^{-1}\right)\end{array}$ & $\begin{array}{c}\text { Lint yield } \\
\left(\mathrm{kg} \mathrm{ha}^{-1}\right)\end{array}$ & $\begin{array}{c}\text { Seed yield } \\
\left(\mathrm{kg} \mathrm{ha}^{-1}\right)\end{array}$ & $\begin{array}{c}\text { Stalk yield } \\
\left(\mathrm{kg} \mathrm{ha}^{-1}\right)\end{array}$ & $\begin{array}{c}\text { Biological } \\
\text { yield } \\
\left(\mathrm{kg} \mathrm{ha}^{-1}\right)\end{array}$ & $\begin{array}{c}\text { Harvest } \\
\text { index } \\
(\%)\end{array}$ & $\begin{array}{c}\text { Total water } \\
\text { productivity } \\
\left(\mathrm{kg} \mathrm{m}^{-3}\right)\end{array}$ \\
\hline Irrigation levels & & & & & & & \\
$\mathrm{I}_{200}$ & 2078 & 594 & 1485 & 3131 & 5210 & 40.25 & 0.405 \\
$\mathrm{I}_{400}$ & 2568 & 734 & 1834 & 4213 & 6781 & 37.95 & 0.360 \\
$\mathrm{I}_{600}$ & 2652 & 758 & 1894 & 4947 & 7599 & 35.91 & 0.290 \\
$\mathrm{SEm} \pm$ & 75 & 21 & 53 & 134 & 195 & 0.43 & 0.011 \\
$\mathrm{CD}(P=0.05)$ & 293 & 84 & 209 & 527 & 767 & 1.70 & 0.044 \\
Nitrogen levels & & & & & & & \\
$\mathrm{N}_{0}$ & 1961 & 560 & 1401 & 3087 & 5049 & 39.22 & 0.285 \\
$\mathrm{~N}_{75}$ & 2241 & 640 & 1601 & 3554 & 5796 & 38.76 & 0.328 \\
$\mathrm{~N}_{150}$ & 2716 & 776 & 1940 & 4745 & 7462 & 36.75 & 0.392 \\
$\mathrm{~N}_{225}$ & 2813 & 803 & 2010 & 5001 & 7815 & 37.41 & 0.400 \\
$\mathrm{SEm} \pm$ & 31 & 9 & 22 & 125 & 128 & 0.74 & 0.004 \\
$\mathrm{CD}(P=0.05)$ & 93 & 26 & 66 & 372 & 379 & $\mathrm{NS}$ & 0.013 \\
\hline
\end{tabular}

$\mathrm{mm}$ gave significantly highest number of bolls per plant which was at par with irrigation level $600 \mathrm{~mm}$ and it was 17.42 per cent higher than irrigation level $200 \mathrm{~mm}$. However, the significantly highest boll weight and seed index were observed with irrigation level $600 \mathrm{~mm}$. The better response may be due to more frequent and optimum supply of irrigation water, which not only increased nutrients availability in root zone but also better uptake of nutrients by the plant as well as better partition of these nutrients in actively growing plant parts. The improved growth evidenced by higher leaf area index and dry matter accumulation with an increased irrigation levels might be responsible for higher yield attributes of cotton at higher irrigation levels observed in this study.

Significantly higher seed cotton yield, lint yield and seed yield were recorded under irrigation at $400 \mathrm{~mm}$, which was statistically at par with $600 \mathrm{~mm}$ and the seed cotton yield was 23.58 percent higher than irrigation level $200 \mathrm{~mm}$. Irrigation level also increased the biological yield of $B t$ cotton. The increase in yield might be due to favourable moisture status in the root zone of the crop through irrigation which favoured better growth and development of plant.The stalk and biological yield increased with increasing level of irrigation and highest values for these parameters were recorded at $600 \mathrm{~mm}$ irrigation level. It was an account of its direct and positive influence on dry matter accumulation and number of bolls per plant as described in preceding paragraphs. The results are in conformity with the findings of Yadav and Chauhan (2013), Yadav and Chauhan (2016).
Nitrogen levels

Number of bolls per plant, boll weight, seed index (Table 1) and seed cotton yield (lint and seed yield), stalk yield, biological yield (Table 2) increased with increasing level of $\mathrm{N}$ application. The significantly highest boll weight, seed index, seed cotton yield, lint yield and seed yield were observed with $\mathrm{N}$ rate $225 \mathrm{~kg} \mathrm{ha}^{-1}$. It was $44.13,13.08$, $43.45,43.39$ and 43.47 per cent higher than nitrogen level $0 \mathrm{~kg} \mathrm{ha}^{-1}$. Further, significantly highest number of bolls per plant, stalk yield and biological yield were observed with $150 \mathrm{~kg} \mathrm{~N}^{-1}$ (Table 2). It was $69.35,53.70$ and 47.79 per cent higher than nitrogen level $0 \mathrm{~kg} \mathrm{ha}^{-1}$. The increase in all these parameters might be due to nitrogen fertilization because nitrogen is way of increasing Leaf area index and the plant enables to produce more branches leading to more number of bolls. The increase in the boll weight with increased $\mathrm{N}$ levels was attributed to increased seed and lint indices of seed cotton. Higher number of bolls with heavier weight under increased nitrogen fertilization together led to more seed cotton yield realization. Nitrogen led enhancement of leaf area culminating in more branches and thus more number of total bolls supports the present result. The present investigation results with respect to seed index in relation to nitrogen fertilization are in tune with the findings of Saleem et al. (2010). The enhanced Bt protein production at higher level of nitrogen fertilization might have led to greater and longer boll worm resistance and thus more boll retention. An increase in boll weight and yield with nitrogen fertilization also reported by Srinivasulu et al. (2006). 
An increase in boll weight, number of branches with increase in nitrogen doses led to significant increase in biological yield. The results corroborate with the findings of Ali et al. (2011), Giri et al. (2014).

\section{Water productivity}

Irrigation levels

The water productivity progressively decreased with a gradual increase in irrigation levels. The application of $200 \mathrm{~mm}$ irrigation recorded highest water productivity closely followed by $400 \mathrm{~mm}$ and $600 \mathrm{~mm}$ irrigation levels (Table 2). The effect of irrigation levels on water productivity is in contrast to its effects on yield, as yield increased with an increase in irrigation levels. The relatively smaller increase in yield compared to amount of irrigation applied with an increase in irrigation levels is explanation of decrease in water productivity at higher irrigation levels observed in present study. The present study was indirectly supported by the findings of Yadav and Chauhan (2013).

\section{Nitrogen levels}

The water productivity increased with an increase in nitrogen levels, although the difference between $150 \mathrm{~kg} \mathrm{~N} \mathrm{ha}^{-1}$ and $225 \mathrm{~kg} \mathrm{~N} \mathrm{ha}^{-1}$ levels were not significant (Table 2). The improvement in water productivity with an increase in nitrogen fertilization observed in the present study might be attributed to increased leaf area which leads to reduction in evaporation component of evapo- transpiration, smaller increase in evapotranspiration compared to yield and better utilization of available soil water. The results are in agreement with the findings of Yadav and Chauhan (2016), who demonstrated that the addition of nitrogen in nitrogen deficient soil increased water productivity, when water is available.

Combined effect of irrigation levels and nitrogen levels

Irrigation along with nitrogen levels significantly influenced the number of bolls per plant, seed cotton yield, stalk yield and water productivity of Bt cotton. Irrigation at $600 \mathrm{~mm}$ and nitrogen rate @ $225 \mathrm{~kg} \mathrm{ha}^{-1}$ significantly improved these parameters in comparison to all the other parameters (Fig. 1, 2, 3 and 4). At the same level of nitrogen, increasing level of irrigation up to $600 \mathrm{~mm}$ significantly increased the number of bolls per plant, seed cotton yield, and stalk yield and water productivity. Similarly, at the same level of irrigation, increasing level of nitrogen up to $225 \mathrm{~kg}$ $\mathrm{N} \mathrm{ha}^{-1}$ significantly increased the number of bolls per plant, seed cotton yield, stalk yield and total water productivity of Bt cotton. The maximum number of bolls per plant, seed cotton yield, stalk yield and total water productivity was observed in $\mathrm{I}_{600} \mathrm{~N}_{225}$ treatment combination while minimum was observed in $\mathrm{I}_{200} \mathrm{~N}_{0}$ treatment combination. These results can be explained by the fact of under water deficit in which the $\mathrm{N}$ was not absorbed in the sufficient amount required for ideal growth. Thus, despite being applied, it was speculated that

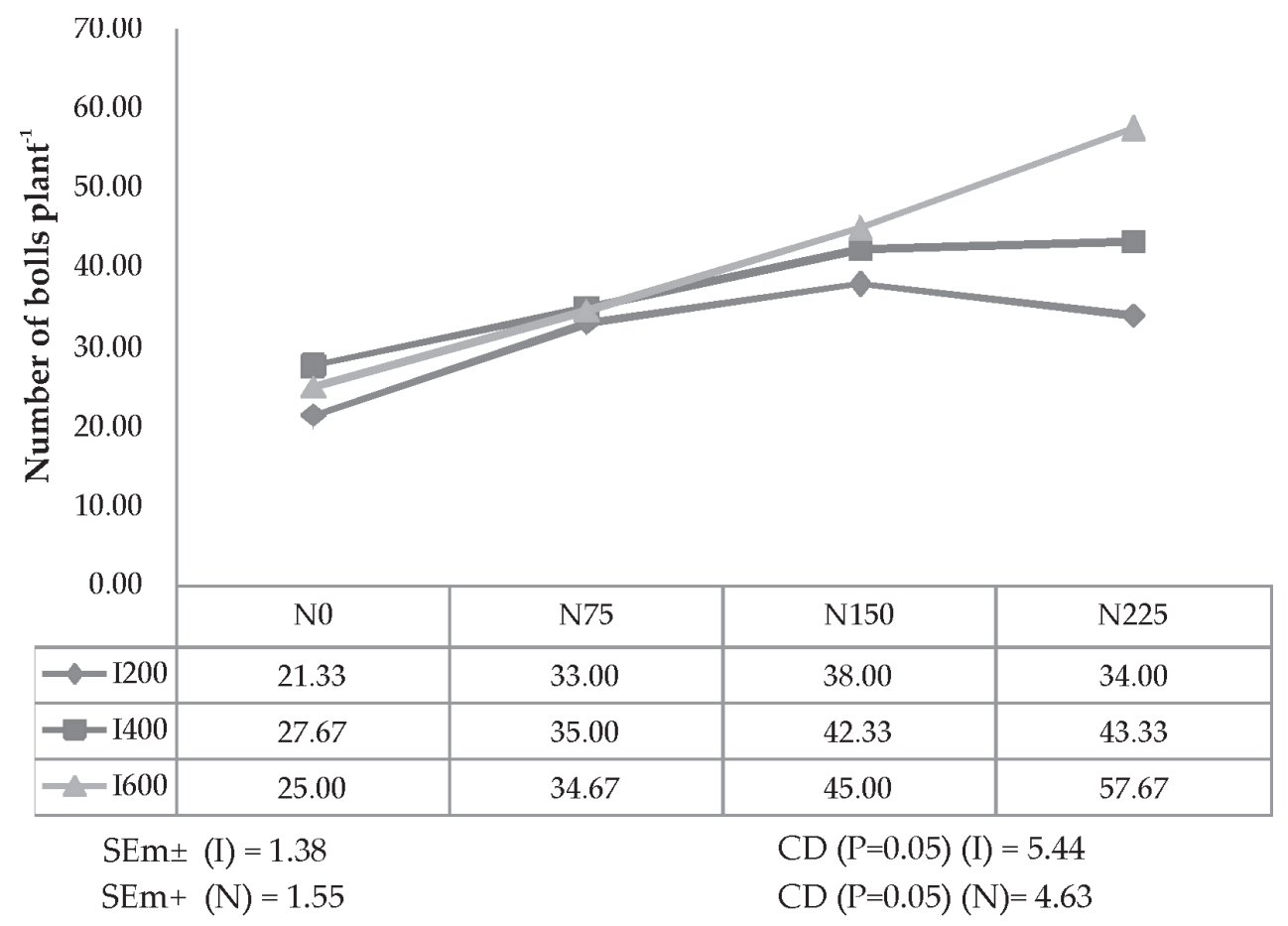

Fig. 1. Combined effect of irrigation and nitrogen levels on number of bolls plant ${ }^{-1}$ of cotton 


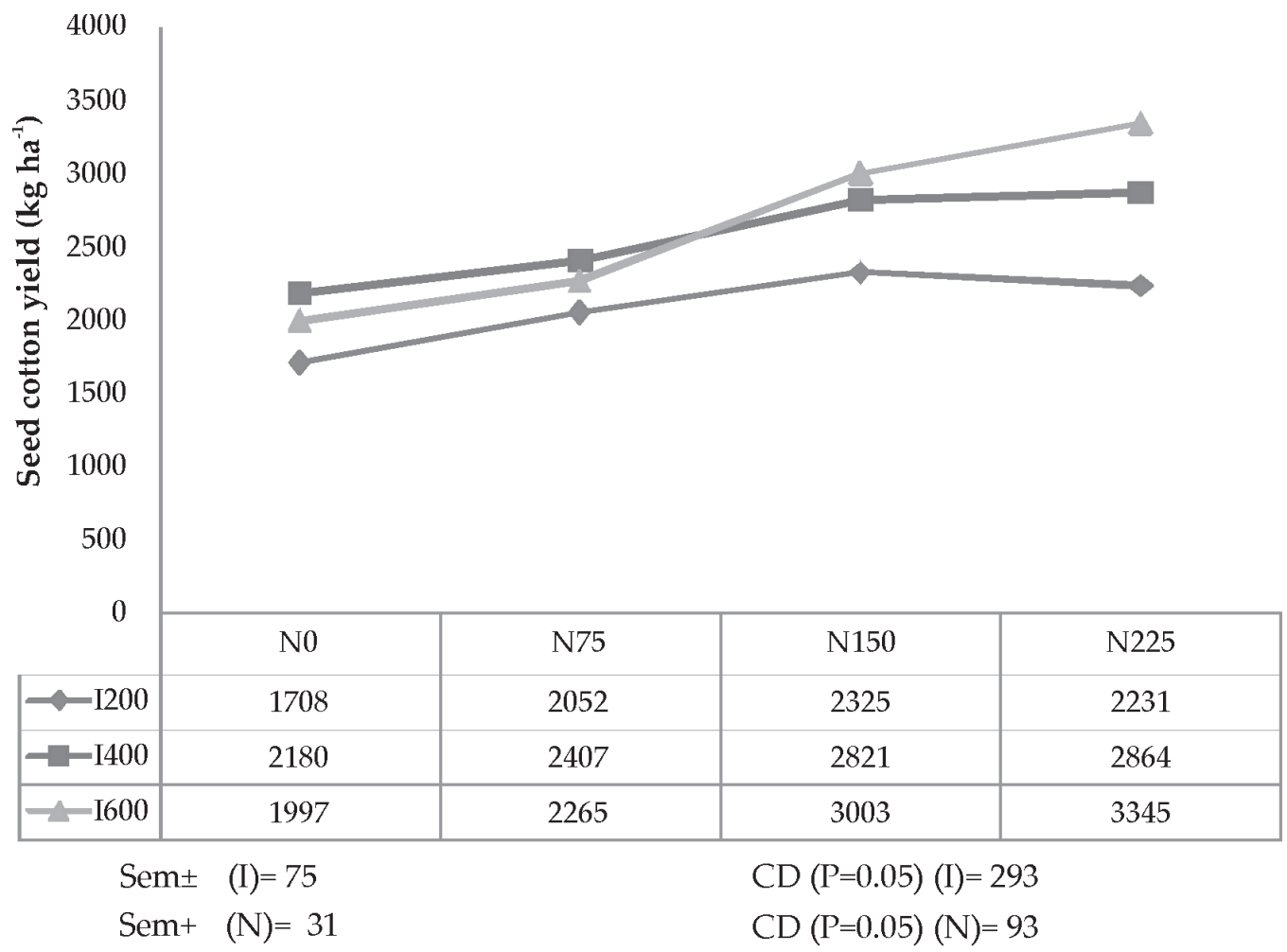

Fig. 2. Combined effect of irrigation and nitrogen levels on seed cotton yield $\left(\mathrm{kg} \mathrm{ha}^{-1}\right)$ of cotton

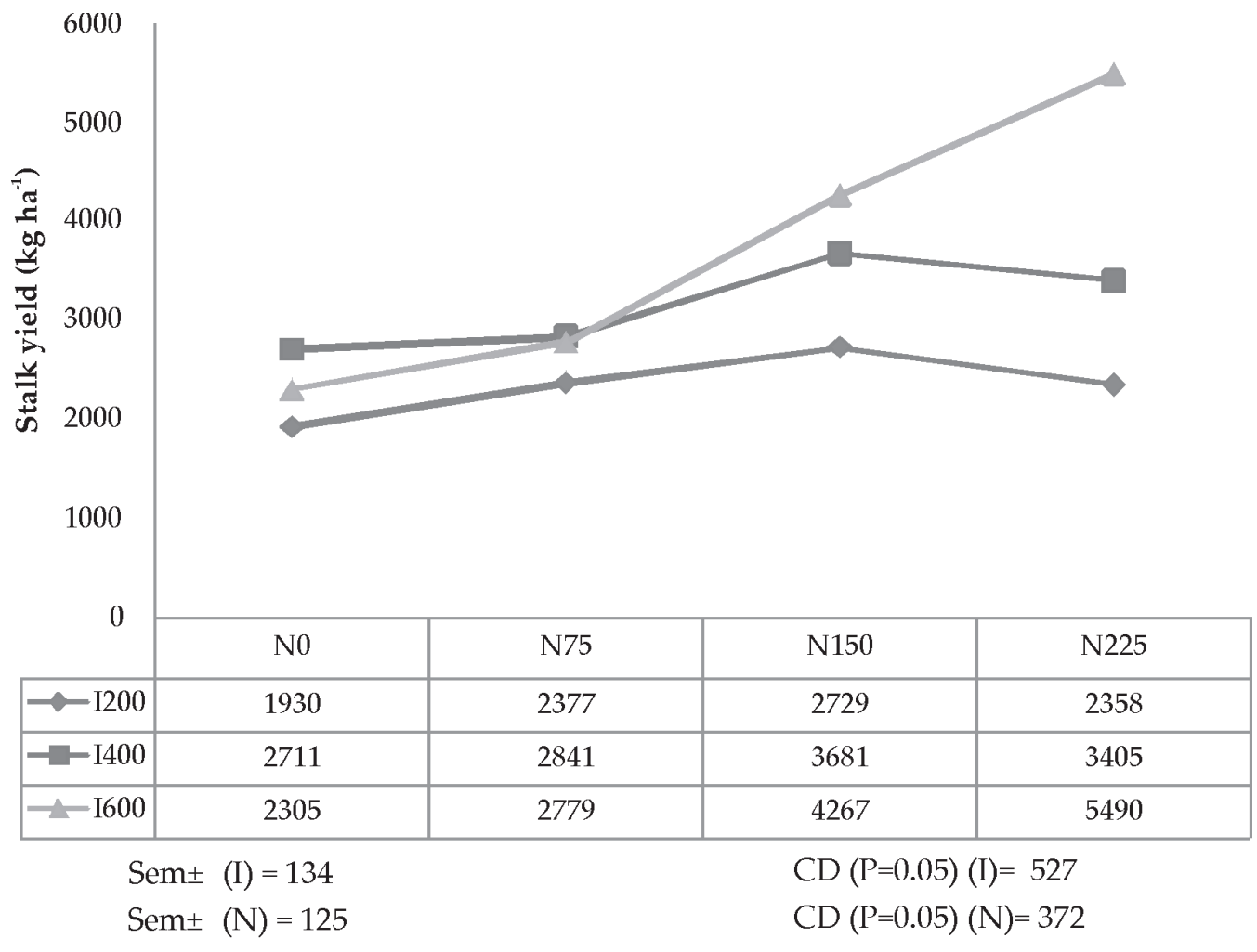

Fig. 3. Combined effect of irrigation and nitrogen levels on stalk yield $\left(\mathrm{kg} \mathrm{ha}^{-1}\right)$ of cotton

$\mathrm{N}$ was lost by volatilization. Further, because of silty clay soils, part of $\mathrm{N}$ was also supposedly lost by leaching. Aujla et al. (2005) remarked that lower N doses, applied in coverage, result in lower productivity regardless of the level of irrigation. The soil water content under ideal condition is important to promote $\mathrm{N}$ uptake by plants. So, the correct water management is essential to avoid waste of inputs. Regarding the water treatments, cotton yield response was linear to the increase in irrigation levels for all $\mathrm{N}$ levels applied. The results of the present study also corroborate with those of Singh et al. (2010). 


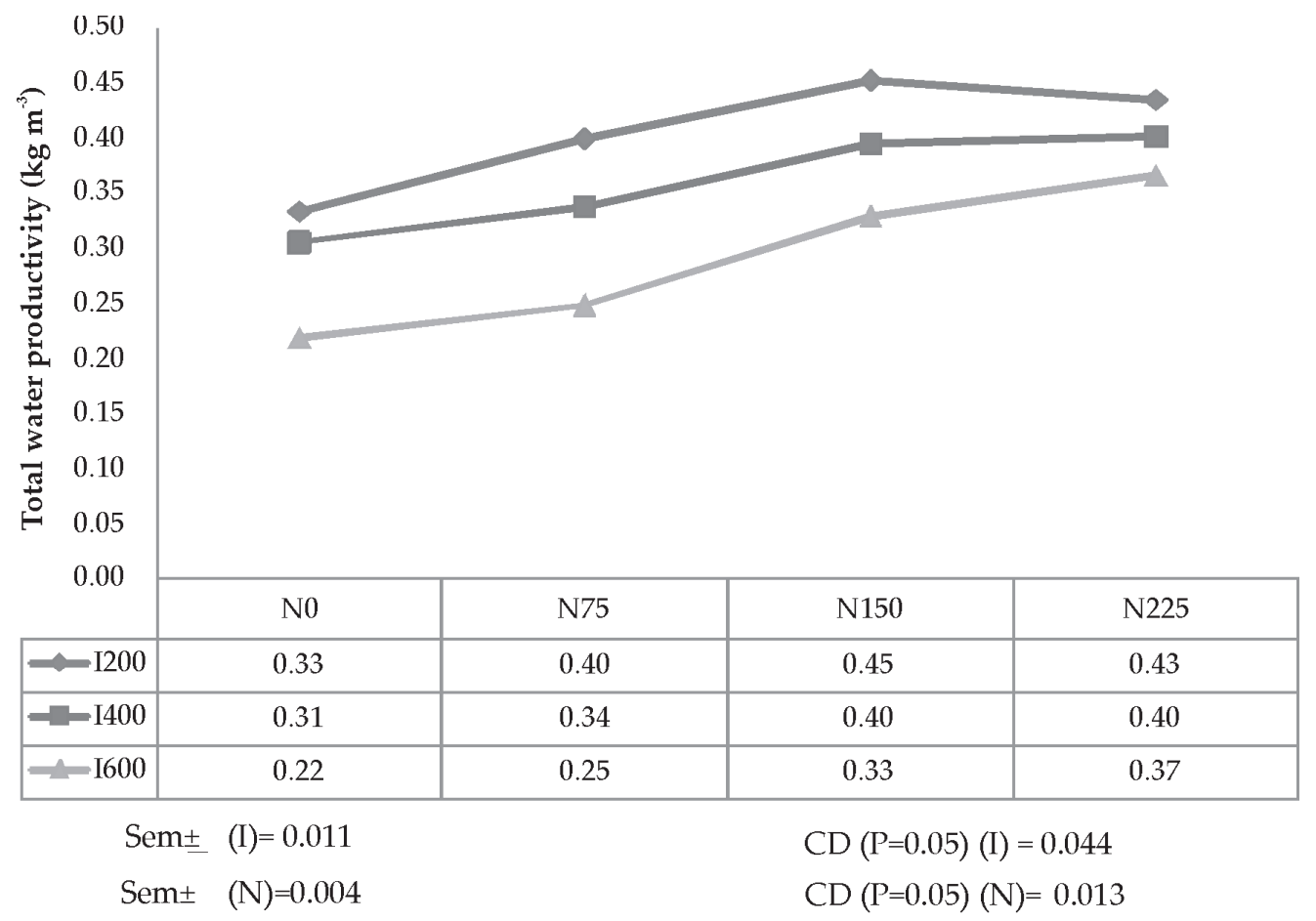

Fig. 4. Combined effect of irrigation and nitrogen levels on total water productivity $\left(\mathrm{kg} \mathrm{m}^{-3}\right)$ of cotton

\section{REFERENCES}

Ali, H., Afzal, M.N., Ahmad, F., Ahmad, S., Akhtar, M. and Atif, R. 2011. Effect of sowing dates, plant spacing and nitrogen application on growth and productivity on cotton crop. International Journal of Scientific $\mathcal{E}$ Engineering Research 2(9): 1-5.

Aujla, M.S., Thind, H.S. and Buttar, G.S. 2005. Cotton yield and water use efficiency at various levels of water and $\mathrm{N}$ through drip irrigation under two methods of planting. Agriculture Water Management 71: 167-179.

Basal, H., Dagdelen, N., Unay, A. and Yilmaz, E. 2009. Effects of deficit drip irrigation ratios on cotton (Gossypium hirsutum L.) yield and fibre quality. Journal of Agronomy Crop Science 195: 19-29.

Cobley, L.S. and Steel, W.M. 1976. Vegetables fibres in an introduction to the botany of tropical crops, $2^{\text {nd }}$ ed. Longman, London: p. 252-257.

Dagdelen, N., Yilmaz, E., Sezgin, F. and Gurbz, T. 2006. Water yield relation and water use efficiency of cotton (Gossypium hirsutum L.) and second crop corn (Zea mays L.) in western Turkey. Agriculture Water Management 82: 63-85.

Giri, M.D., Dhonde, M.B., Bodake, P.S. and Patil, V.S. 2014. Productivity, nutrient uptake and nitrogen-use efficiency of Bt. Cotton (Gossypium hirsutum) in relation to split and foliar application of nitrogen on Inceptisols. Indian Journal of Agronomy 59 (3): 439-444.

Karam, F., Rafic, L., Randa, M., Daccache, A., Mounzer, O. and Rouphael, Y. 2006. Water use and lint yield response of drip irrigated cotton to length of season. Agriculture Water Management. 85: 287-295.

Payero, J.O., Melvin, S.R., Irmak, S. and Tarkalson, D. 2006. Yield response of corn to deficit irrigation in a semiarid climate. Agriculture Water Management 84: 101-112.

Pettigrew, W.T. 2004. Moisture deficit effects on cotton lint yield, yield components, and boll distribution. Agronomy Journal 96: 377-383.
Rao, G.G., Arora, Sanjay, Nikam, V.R. and Sharma, D.K. 2016. Prospects and impact of cultivating salt tolerant varieties of cotton and wheat in coastal saline soils of Gujarat. Indian J. Soil Conservation 44(3): 308-131.

Saleem, M., Bilal, M., Awais, M., Shahid, M. and Anjum, S. 2010. Effect of nitrogen on seed cotton yield and fiber qualities of cotton (Gossypiumm hirsutum L.) cultivars. The Journal of Animal \& Plant Sciences 20 (1): 23-27.

Singh, Y., Rao, S.S. and Regar, P.L. 2010. Deficit irrigation and nitrogen effects on seed cotton yield, water productivity and yield response factor in shallow soils of semi-arid environment. Agriculture Water Management 97: 965-970.

Smith, W.C. 1999. Production statistics. In: Smith, W.C. and Cothren, JT. (Eds.). Cotton, origin, history, technology and production. John Willy and Sons. Inc: 435-449.

Srinivasulu, K., Hema, K., Prasad, N.V.V.S.D. and Krishna Rao, K.V. 2006. Performance of cotton hybrids under different spacings and nitrogen levels in black cotton soils of coastal Andhra Pradesh. Journal of Cotton Research and Development 20: 99-101.

Yadav B.S. and Chauhan R.P.S. 2013 (Eds.). Three decades of research on water management in canal command area of North Western Rajasthan. Agricultural Research Station, SKRAU, Sriganganagar. p.96.

Yadav B.S. and Chauhan R.P.S. 2016. Drip fertigation technology for enhancing water and nutrient use efficiency in arid agro-ecosystem of irrigated NorthWestern Rajasthan. Annals of Arid Zone 55 (3\&4): 139145.

Zegbe-Domínguez, J.A., Behboudian, M.H., Lang, A. and Clothier, B.E. 2003. Déficit irrigation and partial rootzone drying maintain fruit dry mass and enhance fruit quality in "Petoprite" processing tomato (Lycopersicon esculentum, Mill.). Science Horticulture 98: 505-510. 